\title{
Beta Adrenoceptor Blockade Mimics Effects of Stress on Motor Activity in Mice
}

\author{
Eric A. Stone, Ph.D., Sanil J. Manavalan, M.D., Yi Zhang, M.D., \\ and David Quartermain, Ph.D.
}

Reduced central noradrenergic function has been implicated as a factor in reduced behavioral activity after stress. The present studies examined the role of reduced beta adrenergic neurotransmission in mediating this effect. This was done by testing the ability of beta receptor antagonists to mimic the behavioral actions of stress. Mice were subjected to stress or given various beta antagonists and tested for swimming behavior, locomotor activity, or grooming behavior. As previously reported, stress reduced swimming and locomotor activity and increased grooming. Both the nonselective antagonist, l-propranolol, and the beta-1 selective antagonist, betaxolol, produced the same effects as stress on all three measures. A beta-2 selective antagonist, ICI 118,551, was effective only on swimming, whereas a membrane stabilizing agent, d-propranolol, was effective only on grooming behavior. The peripherally active beta-1 antagonist, atenolol, was not effective on any measure. The nonspecific dopaminergic receptor blocker, fluphenazine, reduced locomotion but tended also to reduce grooming. The results indicate that blockade of beta-1 receptors in the CNS selectively mimics the action of stress on gross motor activity in mice and, along with previous data, suggest that stress leads to a relative deficiency in central beta-1 noradrenergic neurotransmission in these animals.

[Neuropsychopharmacology 12:65-71, 1995]
KEY WORDs: Stress; Beta adrenoceptors; Propranolol; Betaxolol; ICI 118,551; Atenolol; Motor activity; Swimming; Grooming

Stress is known to produce a reduction in various types of gross motor activity in rodents. Behaviors affected include locomotor activity in an open field (Stone 1970; Kennett et al. 1985; Armario et al. 1991), exploratory behavior in a maze (Berridge and Dunn 1989), avoidance and escape behavior (Weiss et al. 1975; Anisman et al. 1980) and swimming activity (Simon et al. 1986). Because these changes resemble decreases in psychomotor activity frequently seen in clinical depression and can be reversed by antidepressant treatment, they have been hypothesized to represent a component of an animal model of depression (Stone 1979a; Anisman et al. 1980; Willner 1984; Kennett et al. 1987).

Received March 7, 1994; revised June 2, 1994; accepted July 19, 1994 From the Department of Psychiatry (EAS, SJM, YZ) and the Department of Neurology (DQ), New York University School of Medicine, New York, New York.

Address correspondence to: Dr. Eric Stone, Psychiatry TH HN510, NYU Medical Center, 550 First Ave., New York, NY 10016.
The mechanism by which stress causes hypoactivity has been under investigation for a number of years. One of the factors that has been implicated is a reduced release of brain norepinephrine (NE). The noradrenergic system is known to be involved in the regulation of psychomotor function (Stafford and Jacobs 1990; AstonJones et al. 1991b) and is also known to undergo a decrease in its transmitter during most types of stress (reviewed in Stone 1975). Moreover, agents that enhance NE release prevent or reverse stress-induced behavioral inactivity (Stone 1970; Stone and Mendlinger 1974; Glazer et al. 1975; Anisman et al. 1980; Lehnert et al. 1984), whereas agents that inhibit NE release worsen the hypoactivity (Anisman et al. 1979; Gil et al. 1992).

Although NE release has been implicated, relatively little work has been done to elucidate which postsynaptic adrenergic receptor is involved in this phenomenon. As an initial step toward this end the present experiment was undertaken to explore the role of the beta adrenergic receptor. The latter receptor represents one of the major adrenergic receptors in the forebrain and is 
known to be affected by antidepressant agents (Sulser 1982). There have been isolated reports that blockade of brain beta receptors reduces motor activation (Hermansen 1969; Fabian and Izquierdo 1972; Barar and Madan 1973; Almgren et al. 1978), but the reliability of this effect and the subtypes of receptors involved are presently unclear. The aim of the present experiment was to determine whether blockade of brain beta receptors produces a decrease in motor behavior similar to that produced by stress and, if so, which receptor subtype is involved. For this purpose, mice were administered either stress or one of several beta receptor antagonists and were tested for motor activity. The latter tests included swimming behavior and locomotor activity so as to assess the generality of the findings with regard to different behaviors. A third behavior, grooming, was also recorded because stress has been found to elevate the latter (Gispen and Isaacson 1991), which could therefore serve as a control for nonspecific changes in overall activity.

\section{METHODS}

\section{Animals}

Male Swiss Webster mice (Taconic Farms) 6 to 8 weeks old were used as subjects. The animals were housed in groups of 6 under a 12-hour light/dark cycle (lights on at 0700 hours) with food and water given ad lib.

\section{Stress Administration}

The stress employed was immobilization (IMO) for 1 hour. Immobilization is a behaviorally and physiologically effective form of stress that does not involve the application of painful stimulation. The animal is immobilized on a platform using masking tape to tape the limbs to the platform. Masking tape does not adhere strongly to the skin or fur, so that it can be removed painlessly as determined by the experimenters in tests on themselves. None of the aspects of the stressor are painful as judged from the lack of vocalization of the mice who normally vocalize loudly when in pain (tail pinch or conspecific bite). The stress, however, evokes autonomic (defecation and urination), behavioral (struggling), and neuroendocrine (plasma corticosterone increase) signs of stress. The stress protocol had been approved by the IUCAC of New York University School of Medicine.

\section{MEASUREMENT OF ACTIVITY}

\section{Activity Chamber}

A $30 \times 30 \times 30 \mathrm{~cm}$ aluminum and Plexiglas box was used as the observation chamber. The floor was mopped with water before each animal. Twenty-four hours prior to the test, the animals were habituated for 15 minutes to the chamber. This habituation session was used to reduce the novelty of the chamber. It did not markedly reduce the amount of locomotor activity on subsequent exposure. On the day of the experiment, the animals were placed in the chamber and videotaped for 14 minutes. The tapes were rated by a trained observer who was ignorant of the treatment of the mice. The number of corners the animal visited, defined as $5-\mathrm{cm}$ squares at the corners of the chamber in which the animal entered with all four limbs, was taken as a measure of locomotion. The amount of time the animal engaged in any kind of grooming was taken as the measure of grooming behavior.

\section{Swim Activity}

Swimming activity was measured in a cylinder $16 \mathrm{~cm}$ in diameter and $19 \mathrm{~cm}$ high filled to $12 \mathrm{~cm}$ with $25^{\circ} \mathrm{C}$ water. The animal was immersed in the water and observed for 5 minutes. The amount of time the animal emitted any swimming behavior (paddling movement with the fore or hind limbs) was taken as the measure of active swimming behavior.

\section{Rotorod Test}

Mice were placed on an elevated $(30 \mathrm{~cm})$ wooden cylinder, $11 \mathrm{~mm}$ in diameter, rotating at $6 \mathrm{RPM}$. The time to fall off was recorded. Maximum time was 3 minutes.

\section{Experimental Procedure}

The animals were either administered a drug or given IMO stress prior to the behavioral test. Drugs were administered 2 hours and stress started 1.5 hours prior to the test. The half-hour difference was imposed to allow for absorption of the drug, so that both the drug and the stress would be active for similar lengths of time prior to the test.

\section{Drugs Used}

1-Propranolol, d-propranolol, betaxolol, ICI-118,551, atenolol, fluphenazine, and midazolam were dissolved or diluted in saline. Drugs were administered SC in a volume of $10 \mathrm{ml} / \mathrm{kg}$ ( $20 \mathrm{ml} / \mathrm{kg}$ for atenolol).

\section{RESULTS}

The effects of IMO stress and the above drugs on swimming, locomotion, and grooming are shown in Table 1. Each of the groups in the table was run with a corresponding vehicle control group, and its scores were con- 
Table 1. Effect of Stress and Drugs on Various Forms of Motor Activity in Mice

\begin{tabular}{|c|c|c|c|}
\hline \multirow[b]{2}{*}{ Treatment $^{a}$} & \multicolumn{3}{|c|}{ Percent of Corresponding Control Group } \\
\hline & Swimming & Locomotion & Grooming \\
\hline $\begin{array}{l}\text { IMO stress } \\
\text { 1-Propranolol }\end{array}$ & $82.8 \pm 4.0(18)^{b}$ & $58.1 \pm 6.7(12)^{b}$ & $850.0 \pm 107.6(12)^{b}$ \\
\hline $\begin{array}{c}2 \mathrm{mg} / \mathrm{kg} \\
10 \mathrm{mg} / \mathrm{kg} \\
\text { Betaxolol }\end{array}$ & $\begin{array}{c}\mathrm{ND} \\
80.7 \pm 3.1(12)^{c}\end{array}$ & $\begin{array}{l}87.3 \pm 6.7(9) \\
48.9 \pm 10.7(12)^{d}\end{array}$ & $\begin{array}{l}100.0 \pm 38.6(9) \\
224.6 \pm 40.4(12)^{c}\end{array}$ \\
\hline $\begin{array}{c}2 \mathrm{mg} / \mathrm{kg} \\
10 \mathrm{mg} / \mathrm{kg} \\
\text { ICI } 118,551\end{array}$ & $\begin{array}{c}\mathrm{ND} \\
77.2 \pm 5.8(12)^{d}\end{array}$ & $\begin{array}{l}80.3 \pm 6.8(9) \\
55.8 \pm 5.4(15)^{b}\end{array}$ & $\begin{array}{l}153.1 \pm 37.1(9) \\
264.4 \pm 52.4(15)^{d}\end{array}$ \\
\hline $\begin{array}{c}2 \mathrm{mg} / \mathrm{kg} \\
\text { d-Propranolol }\end{array}$ & $78.4 \pm 4.7(12)^{b}$ & $104.3 \pm 12.2(12)$ & $99.2 \pm 21.4(12)$ \\
\hline $\begin{array}{l}10 \mathrm{mg} / \mathrm{kg} \\
\text { Atenolol }\end{array}$ & $102.1 \pm 4.8(6)$ & $92.5 \pm 9.9(12)$ & $199.6 \pm 36.8(12)^{c}$ \\
\hline $\begin{array}{r}10 \mathrm{mg} / \mathrm{kg} \\
\text { Midazolam }\end{array}$ & $96.7 \pm 4.0(12)$ & $102.7 \pm 11.3(12)$ & $71.7 \pm 23.4(12)$ \\
\hline $\begin{array}{l}1 \mathrm{mg} / \mathrm{kg} \\
\text { Fluphenazine }\end{array}$ & $77.5 \pm 4.1(10)^{b}$ & $71.7 \pm 7.5(12)^{d}$ & $95.2 \pm 27.3(12)$ \\
\hline $0.075 \mathrm{mg} / \mathrm{kg}$ & ND & $40.1 \pm 6.0(6)^{b}$ & $70.7 \pm 32.9(6)$ \\
\hline
\end{tabular}

Values are mean \pm SEM for number of mice in parentheses. Overall mean raw values \pm SD nontreated controls, swimming, $3.94 \pm 0.34 \mathrm{~min}(n=72)$; locomotion, $56.9 \pm 16.0$ corners $(n=99)$; grooming, $2.16 \pm 2.46 \mathrm{~min}(n=99)$. ND $=$ not determined.

${ }^{a}$ Doses in molar equivalents in text.

${ }^{b} p<.001$.

${ }^{c} p<.05$.

${ }^{d} p<.01$.

verted into percentage of mean control. Except where indicated, statistical comparisons were of the planned type and were evaluated by independent $t$-tests between each group and its control.

Immobilization stress significantly decreased swimming and locomotor activity and significantly increased grooming. 1-Propranolol at $10 \mathrm{mg} / \mathrm{kg}(38.6 \mathrm{mmol} / \mathrm{kg})$ significantly reduced both swimming and locomotion and increased grooming. Betaxolol at $10 \mathrm{mg} / \mathrm{kg}(32.6$ $\mathrm{mmol} / \mathrm{kg}$ ) also significantly reduced swimming and locomotion and significantly increased grooming. ICI 118,551 at $2 \mathrm{mg} / \mathrm{kg}$ ( $5.7 \mathrm{mmol} / \mathrm{kg}$ ) significantly reduced swimming behavior but had no effect on locomotor activity or grooming. d-Propranolol at $10 \mathrm{mg} / \mathrm{kg}(38.6$ $\mathrm{mmol} / \mathrm{kg}$ ) had no effect on swimming or locomotor activity but significantly increased grooming behavior. Atenolol at $10 \mathrm{mg} / \mathrm{kg}(37.6 \mathrm{mmol} / \mathrm{kg})$ had no effect on swimming, locomotion, or grooming. Fluphenazine at $0.075 \mathrm{mg} / \mathrm{kg}(0.17 \mathrm{mmol} / \mathrm{kg})$ significantly reduced locomotion but did not significantly alter grooming although it tended to decrease the latter (swimming not examined). Midazolam at $1 \mathrm{mg} / \mathrm{kg}(3.1 \mathrm{mmol} / \mathrm{kg}) \mathrm{sig}$ nificantly reduced swimming and locomotion but had no effect on grooming.

An additional group of animals was administered betaxolol $(10 \mathrm{mg} / \mathrm{kg}) 0.5$ hour rather than 2 hours prestress and tested as above. The results were not significantly different from those above (data not shown).

Rotorod performance was not affected by stress or betaxolol $10 \mathrm{mg} / \mathrm{kg}$ ( $32.6 \mathrm{mmol} / \mathrm{kg}$ ) (means and SEMs, control $1.51 \pm 0.20 \mathrm{~min}$, IMO stress, $1.52 \pm 0.18$, betaxolol, $1.09 \pm 0.19$ (all $n s=12$, one way analysis of variance not significant).

\section{DISCUSSION}

The present results show that blockade of central beta adrenoceptors can mimic the changes in gross motor activity produced by acute stress in mice. In agreement with past research (cited in the introduction), IMO stress was found to reduce two forms of motor activity, swimming and locomotion, and elevate a third, grooming. 1-Propranolol, which is known to block both beta- 1 and beta- 2 receptors, resulted like stress in a reduction in swimming and locomotor activity and an increase in grooming. The effects of l-propranolol on swimming and locomotion were not a result of its membrane stabilizing property because d-propranolol, which has an identical membrane stabilizing effect but lacks beta receptor activity had no effects on these behaviors (see below for grooming). The selective beta-1 receptor blocker, betaxolol, also reproduced all three effects of stress and did so at a dose that has been reported to be selective for beta- 1 receptors in the rat brain (Tondo et al. 1985). The effects of 1-propranolol and betaxolol on locomotor activity and grooming appear to be a result of their beta- 1 antagonist action because the selec- 
tive beta- 2 antagonist, ICI 118,551, had no effect on these behaviors. The latter drug did, however, produce a decrease in swimming indicating possible involvement of both beta- 2 and beta- 1 receptors in this behavior.

The extent to which membrane stabilizing effects of these drugs were involved in the increase in grooming behavior is not presently clear. Both d-propranolol, which has a membrane stabilizing effect, and betaxolol, which does not (Cavero et al. 1983), produced an equivalent increase in grooming behavior. It is possible therefore that both membrane stabilization and beta- 1 receptor blockade can produce an increase in grooming behavior.

The syndrome of reduced locomotion and swimming coupled with an increase in grooming appears to be selective to blockade of noradrenergic receptors. Fluphenazine, which nonselectively blocks dopaminergic receptors, reduced locomotion but did not increase grooming. In fact, it tended to reduce the latter in agreement with the findings that dopamine receptor blockade produces a more general depressant effect on all forms of active behavior.

That the behavioral effects of the above drugs were a result of their actions on central rather than peripheral beta adrenoceptors was shown by the finding that the peripherally active beta- 1 antagonist had no effect on any of the above behaviors.

The present results thus confirm and extend earlier findings that beta receptor blockers can induce a reduction in evoked gross motor activity in the mouse (cited in the introduction). Presumably, there is sufficient evoked activity in locus coeruleus neurons during these behavioral tests to cause significant activation of postsynaptic brain beta receptors by NE (Rasmussen et al. 1986). They also demonstrate the novel finding that these drugs increase the level of grooming behavior. The results indicate therefore that blockade of beta- 1 receptors can mimic the effects of stress on a variety of active behaviors in mice. This finding suggests that a deficient noradrenergic neurotransmission at beta- 1 receptors is a factor in producing changes in motor activity after stress.

The present findings would appear to disagree with those of Gorman and Dunn (1993), who have found that beta blockers tend to antagonize effects of stress on emergence and exploratory behavior. We did not use the same tests as Gorman and Dunn in the present experiment, although in a separate study we have found that propranolol lengthens the increase in latency caused by stress in an emergence test similar to the one these authors used (Stone et al. 1994). Also, Gorman and Dunn utilized singly housed VAF plus CD-1 mice, whereas we used group-housed Swiss Webster mice, which may have caused the difference.

What aspect of beta-1 noradrenergic transmission is reduced by stress is not known. It has been suggested on the basis of stress-induced depletion of brain NE and the effects of drugs that alter brain levels of NE that NE release is reduced post stress possibly in response to an excessive release during stress (Stone 1970; Weiss et al. 1975; Anisman et al. 1980; Lehnert et al. 1984). However, most dialysis studies of brain NE release have not found a poststress decrease (Abercrombie et al. 1988), and a number have reported persistent poststress increases (Yokoo et al. 1990; Tanaka et al. 1991). Also, measures of locus coeruleus unit activity (Simson and Weiss 1988) and of NE turnover in the brain (Stone 1973; Lehnert et al. 1984) after stress have supported a persistent poststress increase in NE release. Another possibility is that the need for NE at these receptors is increased by stress, (i.e., the system needs a greater input of NE to function normally after stress). In this regard, Lehnert et al. (1984) found that the NE precursor, tyrosine, was effective in restoring motor activity after stress and that it increased NE turnover beyond the already elevated poststress level. This suggests that neuronal systems postsynaptic to the noradrenergic require a greater NE input following stress and that failure to maintain this heightened input might lead to a relative noradrenergic deficiency. A third possibility is that the reduced neurotransmission at these receptors results from receptor desensitization. Prolonged agonist exposure is known to result in the desensitization and/or downregulation of neurotransmitter receptors. It has been found that stress produces a desensitization and/or downregulation of alpha-1 (Stone 1979b) and beta (Torda et al. 1981) receptors, which would reduce transmission accordingly. Further research will be required to determine how each of these factors is involved in the putative reduction of brain beta- 1 neurotransmission after stress.

Precisely what the reduced swimming and locomotor activity and the increased grooming behavior after stress represent and how they are functionally related to beta adrenoceptors is not completely understood. There are several possibilities, however. One factor is impaired motor function. Weiss and Glazer (1975) proposed that hypoactivity following stress results from a motor activation deficit because they found that stressed rats had more difficulty learning effortful than effortless tasks. This is in agreement with findings that central noradrenergic neurons are involved in the control of motor functions (Stafford and Jacobs 1990). However, it does not agree with the findings that both stressed and beta-blocked animals showed increases in grooming, and that neither stressed nor betaxololtreated mice showed impaired rotorod performance.

A second factor that may be involved is fear. Noradrenergic mechanisms and stress have been implicated in fear behavior (Berridge and Dunn 1989; Charney et al. 1992). It is unlikely, however, that fear 
was an important factor in inducing hypoactivity because stressed animals were observed to spend less than $5 \%$ of their time freezing in the activity chamber. An alternative possibility is that fear motivated the active behavior of the animals in the chamber and swimming tests and that a reduction in fear caused by the beta blockers and stress resulted in reduced activity (Gorman and Dunn 1993; Kurose et al. 1993). This is supported by the finding that midazolam produced similar effects as beta-blockers and stress on swimming and locomotion. Although stress is not generally thought to produce a reduction in anxiety, it is possible that under some circumstances it can desensitize fear responses (Deakin and Graeff 1991).

A final possibility is that the hypoactivity after stress represents a diminished motivation to interact with the environment and that the increased grooming represents a turning inward of attentional processes. According to this view as a result of stress, active behavior directed at the environment is less reinforcing and consequently there is an increase of self-directed activities such as grooming. This is supported by the findings that stress reduces the rewarding effects of brain stimulation (Zacharko et al. 1983, 1984), sweet solutions (Willner et al. 1987) and amphetamine (Papp et al. 1991) and that beta adrenoceptors have been implicated in mechanisms of reinforcement (Watson and McElligott 1984; McElligott and Freedman 1988; Decker et al. 1990; Crowe et al. 1991) and attentional processes (Berridge and Foote 1991). Moreover, noradrenergic activity in the locus coeruleus is inversely correlated with self-directed activities such as grooming (Aston-Jones et al. 1991a), and under some conditions there is an inverse correlation between brain noradrenergic activity and the concentration of corticotropin releasing factor (Brady et al. 1991; Veith et al. 1993), a neuropeptide implicated in stressinduced grooming (reviewed in Dunn and Berridge 1990).

Based on the above considerations we propose that stress causes a disturbance or an excessive need for beta- 1 adrenergic neurotransmission in the brain and that this change, which can be mimicked by beta- 1 blockers, produces changes in the level of fear and/or other motivations such that the animal shows less externally and more self-directed motor activity.

\section{ACKNOWLEDGMENT}

Supported in part by grants MH45265, AFOSR F49620-92-J0084, and MH08618.

\section{REFERENCES}

Abercrombie ED, Keller RW, Zigmond MJ (1988): Characterization of hippocampal norepinephrine release as measured by microdialysis perfusion: Pharmacological and behavioral studies. Neuroscience 27:897-904
Almgren O, Engel J, Jonason J (1978): Central effects of beta adrenoceptor antagonists. In Catecholamines: Barchas J, Basic and Clinical Frontiers. Usdin E, Kopin IJ (eds), New York, Pergamon Press. pp. 589-591

Anisman H, Remington G, Sklar LS (1979): Effect of inescapable shock on subsequent escape performance: Catecholaminergic and cholinergic mediation of response initiation and maintenance. Psychopharmacology 61:107-124

Anisman H, Suissa A, Sklar LS (1980): Escape deficits induced by uncontrollable stress: Antagonism by dopamine and norepinephrine agonists. Behav Neurol 28:34-47

Armario A, Gil M, Marti J, Pol O, Balasch J (1991): Influence of various acute stressors on the activity of adult male rats in a holeboard and in the forced swim test. Pharmacol Biochem Behav 39:373-377

Aston-Jones G, Chiang G, Alexinsky T (1991a): Discharge of noradrenergic locus coeruleus neurons in behaving rats and monkeys suggests a role in vigilance. Prog Brain Res 88:501-520

Aston-Jones G, Shipley MT, Chouvet G, Ennis M, Van Bockstaele E, Pieribone V, Shiekhattar R, Akaoka H, Drolet G, Astier B, Charlety P, Valentino RJ, Williams JT (1991b): Afferent regulation of locus coeruleus neurons: Anatomy, physiology and pharmacology. Prog Brain Res 88:47-75

Barar FSK, Madan BR (1973): Effect of ten beta-adrenoceptor blocking agents on spontaneous motility and pentobarbital induced anaesthesia in mice. Indian J Physiol Pharmacol 17:235-240

Berridge CW, Dunn AJ (1989): Restraint-stress-induced changes in exploratory behavior appear to be mediated by norepinephrine-stimulated release of CRF. J Neurosci 9:3513-3521

Berridge CW, Foote SL (1991): Effects of locus coeruleus activation on electroencephalographic activity in neocortex and hippocampus. J Neurosci 11:3135-3145

Brady LS, Whitfield HJ Jr, Fox RJ, Gold PW, Herkenham M (1991): Long-term antidepressant administration alters corticotropin-releasing hormone, tyrosine hydroxylase, and mineralocorticoid receptor gene expression in rat brain. J Clin Invest 87:831-837

Cavero I, Lefevre-Borg F, Manoury P, Roach A (1983): In vitro and in vivo pharmacological evaluation of betaxolol, a new and potent selective beta-1 adrenoceptor antagonist. In Cavero I, Morselli PL, Kolborn JR, Harrison DC, Langer SZ (eds), Betaxolol and Other Beta-1 Adrenoceptor Antagonists, New York, Raven Press, pp 31-42

Charney DS, Woods SW, Krystal JH, Nagy LM, Heninger GR (1992): Noradrenergic neuronal dysregulation in panic disorder: The effects of intravenous yohimbine and clonidine in panic disorder patients. Acta Psychiatr Scand 86:273-282

Crowe SF, Ng KT, Gibbs ME (1991): Possible noradrenergic involvement in training stimulus intensity. Pharmacol Biochem Behavior 39:717-722

Deakin JWW, Graeff FG (1991): 5-HT and mechanisms of defence. J Psychopharmacol 5:305-315

Decker MW, Michael Gill T, McGaugh JL (1990): Concurrent muscarinic and $\beta$-adrenergic blockade in rats impairs place-learning in a water maze and retention of inhibitory avoidance. Brain Res 513:81-85

Dunn AJ, Berridge CW (1990): Physiological and behavioral 
responses to corticotropin-releasing factor administration. Is CRF a mediator of anxiety or stress responses? Brain Res Rev 15:71-100

Fabian HEM, Izquierdo JA (1972): The effect of propranolol and alprenolol on spontaneous motility of mice. Arzneim Forsch 22:1553

Gil M, Marti J, Armario A (1992): Inhibition of catecholamine synthesis depresses behavior of rats in the holeboard and forced swim tests: Influence of previous chronic stress. Pharmacol Biochem Behavior 43:597-601

Gispen WH, Isaacson RL (1981): ACTH-induced excessive grooming in the rat. Pharmacol Ther 12:209-246

Glazer HI, Weiss JM, Pohorecky LA, Miller NE (1975): Monoamines as mediators of avoidance-escape behavior. Psychosom Med 37:535-543

Gorman AL, Dunn AJ (1993): Beta-adrenergic receptors are involved in stress related behavioral changes. Pharmacol Biochem Behav 45:1-7

Hermansen K (1969): Effect of different beta-adrenergic receptor blocking agents on hexobarbital induced narcosis in mice. Acta Pharmacol Toxicol 27:453-460

Kennett GA, Dickinson SL, Curzon G (1985): Enhancement of some 5-HT-dependent behavioural responses following repeated immobilization in rats. Brain Res 330:253-263

Kennett GA, Dourish CT, Curzon G (1987): Antidepressantlike action of 5-HT1A agonists and conventional antidepressants in an animal model of depression. Eur J Pharmacol 134:265-274

Kurose H, Arriza JL, Lefkowitz RJ (1993): Characterization of alpha2-adrenergic receptor subtype-specific antibodies. Molec Pharmacol 43:444-450

Lehnert H, Reinstein DK, Strowbridge BW, Wurtman RJ (1984): Neurochemical and behavioral consequences of acute, uncontrollable stress: Effects of dietary tyrosine. Brain Res 303:215-223

McElligott JG, Freedman W (1988): Vestibulo-ocular reflex adaptation in cats before and after depletion of norepinephrine. Exp Brain Res 69:509-521

Papp M, Willner P, Muscat R (1991): An animal model of anhedonia: Attenuation of sucrose consumption and place preference conditioning by chronic unpredictable mild stress. Psychopharmacology 104:255-259

Rasmussen K, Morilak DA, Jacobs BL (1985): Single unit activity of locus coeruleus neurons in the freely moving cat. I. During naturalistic behaviors and in response to simple and complex stimuli. Brain Res 371:324-334

Simson PE, Weiss JM (1988): Altered activity of the locus coeruleus in an animal model of depression. Neuropsychopharmacology 1:287-295

Simson PG, Weiss JM, Hoffman LJ, Ambrose MJ (1986): Reversal of behavioral depression by infusion of an alpha-2 adrenergic agonist into the locus coeruleus. Neuropharmacology 25:385-389

Stafford IL, Jacobs BL (1990): Noradrenergic modulation of the masseteric reflex in behaving cats. I. Pharmacological studies. J Neurosci 10:99-107

Stone EA (1970): Swim-stress-induced inactivity: Relation to body temperature and brain norepinephrine, and effects of d-amphetamine. Psychosom Med 32:51-59
Stone EA (1973): Adrenergic activity in rat hypothalamus following extreme muscular exertion. Am J Physiol 224: 165-169

Stone EA (1975): Stress and catecholamines. In Friedhoff AJ (ed), Catecholamines and Behavior, New York, Plenum Press. pp 31-72

Stone EA (1979a): Subsensitivity to norepinephrine as a link between adaptation to stress and antidepressant activity: An hypothesis. Res Comm Psychol Psychiat Behav 4:241-255

Stone EA (1979b): Reduction by stress of norepinephrinestimulated accumulation of cyclic AMP in rat cerebral cortex. J Neurochem 32:1335-1337

Stone EA, Mendlinger S (1974): Effect of intraventricular amines on motor activity in hypothermic rats. Res Comm Chem Pathol Pharmacol 7:549-556

Stone EA, Najimi M, Quartermain D (1994): Potentiation by propranolol of effect of stress on passive avoidance and open field emergence test in mice. Pharmacol Biochem Behav (in press)

Sulser F (1982): Antidepressant drug research: Its impact on neurobiology and psychobiology. In Costa E, Racagni G. (eds), Typical and Atypical Antidepressants: Molecular Mechanisms. New York, Raven Press

Tanaka T, Yokoo H, Mizoguchi K, Yoshida M, Tsuda A, Tanaka M (1991): Noradrenaline release in the rat amygdala is increased by stress: Studies with intracerebral dialysis. Brain Res 544:174-176

Tondo L, Conway PG, Brunswick DJ (1985): Labeling in vivo of beta adrenergic receptors in the central nervous system of the rat after administration of [125-I]iodopindolol. J Pharmacol Exp Ther 235:1-9

Torda T, Yamaguchi I, Hirata F, Kopin IJ, Axelrod J (1981): Mepacrine treatment prevents immobilization-induced desensitization of beta-adrenergic receptors in rat hypothalamus and brain stem. Brain Res 205:441-444

Veith RC, Lewis N, Langohr JI, Murburg MM, Ashleigh EA, Castillo S, Peskind ER, Pascualy M, Bissette G, Nemeroff CB, Raskind MA (1993): Effect of desipramine on cerebrospinal fluid concentrations of corticotropinreleasing factor in human subjects. Psychiat Res 46:1-8

Watson M, McElligott JG (1984): Cerebellar norepinephrine depletion and impaired acquisition of specific locomotor tasks for rats. Brain Res 296:129-138

Weiss JM, Glazer HI (1975): Effects of acute exposure to stressors on subsequent avoidance-escape behavior. Psychosom Med 37:499-521

Weiss JM, Glazer HI, Pohorecky LA, Brick J, Miller NE (1975): Effects of chronic exposure to stressors on avoidanceescape behavior and on brain norepinephrine. Psychosom Med 37:522-534

Willner P. (1984): The validity of animal models of depression. Psychopharmacology 83:1-16

Willner P, Towell A, Sampson D, Sophokleous S, Muscat R (1987): Reduction of sucrose preference by chronic unpredictable mild stress, and its restoration by a tricyclic antidepressant. Psychopharmacology 93:358-364

Yokoo H, Tanaka M, Tanaka T, Tsuda A. (1990): Stressinduced increase in noradrenaline release in the rat 
hypothalamus assessed by intracranial microdialysis. Experientia 46:290-292.

Zacharko RM, Bowers WJ, Kokkinidis L, Anisman H (1983): Region-specific reductions of intracranial self-stimulation after uncontrollable stress: Possible effects of reward processes. Behav Brain Res 9:129-141

Zacharko RM, Bowers WJ, Kelley MS, Anisman H (1984): Prevention of stressor-induced disturbances of selfstimulation by desmethylimipramine. 321:175-179 